\title{
Dagbesteding en cognitieve stoornissen
}

1. Volgens Groen-Van de Ven et al. zijn er drie sleutelmomenten in het besluitvormingsproces rond dagbesteding. Onder andere de aanvankelijke verwachtingen van dagbesteding spelen een belangrijke rol in de beslissing. Kinderen van personen met dementie hebben vaak positieve verwachtingen van dagbesteding, in tegenstelling tot de dementerenden zelf. Hoe staan hun partners over het algemeen tegenover dagbesteding?
a. Positief
b. Neutraal
c. Negatief

2. Groen-Van de Ven et al. onderzochten op basis waarvan voorkeuren over dagbesteding veranderen. Strategieën zijn onder andere het verstrekken van informatie en het uitproberen van dagbesteding. Van welke strategieën is gebleken dat ze leiden tot verandering van voorkeuren?

a. Alleen van informeren

b. Van zowel informeren als uitproberen

c. Alleen van uitproberen

3. Groen-Van de Ven et al. onderscheiden drie beslistrajecten in de besluitvorming. In het derde beslistraject wordt geen commitment bereikt voor het uitproberen van dagbesteding. Kenmerkend aan dit traject is dat het initiatief voor het bespreken van dagbesteding komt van zorgverleners. Wordt in dit traject gesproken over alternatieven?

a. Ja, op initiatief van de mantelzorgers

b. Ja, op initiatief van de zorgverleners

c. Nee
4. Zowel de kloktekentest als de Montreal Cognitive Assessment (MoCA) zijn geschikt om cognitieve stoornissen uit te sluiten op het moment dat deze niet waarschijnlijk zijn. Janssen et al. hebben een voorkeur voor de kloktekentest. Waarop is dit gebaseerd?
a. De kortere afnametijd van de kloktekentest
b. De ruime ervaring met de klok- tekentest
c. De MoCA is gevoeliger voor inter- beoordelaarvariatie
d. De MoCA is minder geschikt voor hogeropgeleiden

5. Janssen et al. bevelen de Mini Mental State Examination (MMSE) aan in situaties waarin een cognitieve stoornis waarschijnlijk wordt geacht. De MMSE heeft echter niet in alle situaties diagnostische meerwaarde. Voor welke situatie geldt dit?
a. De patiënt is hoogopgeleid met milde cognitieve klachten
b. De patiënt is laagopgeleid met milde cognitieve klachten
c. De patiënt is hoogopgeleid met forse cognitieve klachten
d. De patiënt is laagopgeleid met forse cognitieve klachten

6. De huisarts is op visite bij de 68-jarige heer Akdeniz. Hij heeft de ziekte van Alzheimer. De huisarts vraagt de heer Akdeniz om hem de pen aan te geven die naast hem op tafel ligt. De heer Akdeniz kijkt in de richting van de pen, maar lijkt die niet te herkennen en geeft de pen dus ook niet aan. Hoe heet dit verschijnsel?
a. Agnosie
b. Amnesie
c. Anosmie
d. Apraxie

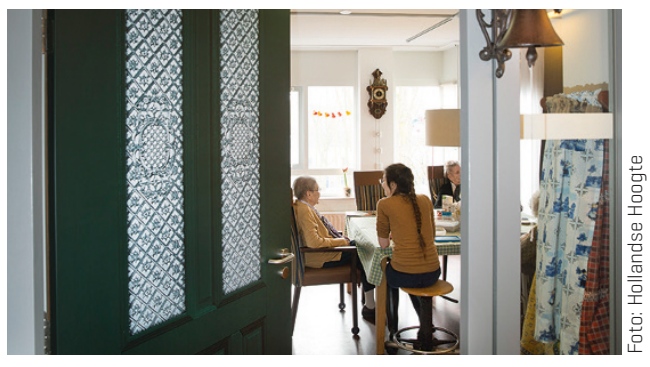

7. Aios en opleider bespreken het afnemen van de MMSE. Waarvan geeft de MMSE een globale indruk?

a. Van de cognitieve functies

b. Van de uitvoerende functies

c. Van het abstracte denken

d. Van het concrete denken

8. Mevrouw Vaartjes is 82 jaar en wordt de laatste tijd steeds vergeetachtiger. Tijdens het gesprek haalt ze zaken door elkaar en gebruikt ze woorden die niet in de zin passen. Lichamelijk en laboratoriumonderzoek leveren geen afwijkingen op. De huisarts overweegt de diagnose dementie. Wat is nodig om de diagnose dementie te kunnen stellen?

a. Informatie over het dagelijks functioneren

b. De uitslag van de MMSE

c. Verwijzing naar de neuroloog

De kennistoets is gemaakt door Anne Klijnsma, werkzaam bij Huisartsopleiding Nederland. Over vragen en antwoorden wordt niet gecorrespondeerd.

\section{GEBRUIKTE BRONNEN}

Groen-Van de Ven L, Smits C, De Graaff F, et al. Dagbesteding bij dementie. Samen met mensen met dementie beslissen. Huisarts Wet 2018;61[8]:18-21. DOI: 10.1007/s-12445-0180218-9.

Janssen J, Koekkoek P, Moll Van Charante E, et al. Hoe weet je of cognitieve stoornissen waarschijnlijk zijn? Huisarts Wet 2018;61[8]:14-7. DOI: 10.1007-s12445-018-0222-0.

Moll van Charante E, Perry M, Vernooij-Dassen MJFJ, et al. NHG-Standaard Dementie [derde herziening]. www.nhg.org

\section{ANTWOORDEN}

e8 / eL / eg / es / eh / כe / כ / כ 